\title{
Migrants, states, and EU citizenship's unfulfilled promise
}

\author{
Willem Maas* \\ Department of Political Science, Glendon College, York University, Toronto, Canada
}

(Received 27 June 2008; final version received 5 August 2008)

\begin{abstract}
A constant aim of EU citizenship, and indeed the entire project of European integration, has always been to lower barriers and create a common space. If the complete elimination of national borders remains elusive, their importance has been diminished in striking ways by the development of EU citizenship and the ban against nationality based discrimination. Yet the barriers to free movement have been lowered in differential ways. Most citizens of EU member states now enjoy residence, employment and other rights throughout Europe. The extension of some rights to some categories of citizens of some new member states is admittedly sometimes subject to transition periods, but these expire. By contrast, third country nationals - individuals who do not hold citizenship of one of the member states, even though they may have resided for many years, or even been born in Europe - remain largely excluded from the benefits of EU citizenship. Various initiatives over the years have opened up limited rights for third country nationals. But the difficulty of enacting these rights, and current moves to more restrictive immigration and naturalization policies, highlight the continuing exclusivity of EU citizenship: immigrants migrate to national polities, and they become European only by virtue of incorporation into national states. This means that EU citizenship's transformative potential remains unrealized.
\end{abstract}

Keywords: nested citizenship; free movement; migration; residence; employment; naturalization; nationality law; third country nationals; nondiscrimination

\section{Introduction}

Free movement has always been a key value and objective of European integration: ${ }^{1}$ not only the free movement of goods, services, and capital but also the free movement of people within the shared European space. Indeed, much in common with earlier examples of nation-state formation, free movement can be viewed as the bedrock upon which the entire construction of European rights has been built. Free movement of persons achieves economic objectives but also nurtures a supranational community. Thus, European integration is not simply an economic project but also a political one aimed at creating a common status and common rights - a community of people rather than simply a free market (Maas 2007, p. 5). This ideal of a European citizenship was reflected in the argument of some participants to the 1948 Congress of Europe that 'a European nationality must be created' and that a 'harmonious society in Europe' would develop only 'when the petty rivalries of national states have been laid aside' (resolution of the Economic and Social Committee). Alongside economic aims, a founding principle of European integration was that only a 'genuine European political community' would safeguard the European values of life, freedom, dignity, social justice and, above all, peace (French prime

\footnotetext{
*Email: maas@yorku.ca 
minister Guy Mollet, cited in Maas 2007, p. 5). While not denying the importance of the economic arrangements they were establishing, Europe's political leaders saw these arrangements as 'merely accessory to, or, at the very least, the first stage of a yet greater political revolution' (Belgian foreign minister Paul-Henri Spaak, cited in Maas 2007, p. 5).

This 'political revolution' has resulted in a common European status (gradually formalized as European citizenship), common European rights attached to that status, and an incipient common European identity (compare Joppke, this volume). The expansion of rights has given content to European citizenship but the meaning of European identity remains in question (compare Bellamy, this volume). The motto that portrays Europe as 'united in diversity' captures this tension. Freedom of movement as the key right of European citizenship may be a common value, but its emotive power is far from the deeply entrenched values evoked by citizenship in most national states. Former Commission president Jacques Delors wisely noted that it is difficult to fall in love with a common market' (cited in Maas 2007, p. 95) suggesting that Europe needed to move beyond a focus on the market in order to develop popular loyalty and devotion. European rights were intended to accomplish this, yet it seems unlikely that European rights alone will lead to a well-developed common European identity, let alone the patriotism that characterizes many national identities.

Six decades after the Congress of Europe, the grand project of turning the whole of Europe into one space has been largely achieved. Excepting transitional periods for some nationals of some new member states and a few rarely invoked limitations based on national security, health, or public policy, citizens of EU member states may now move freely within the common territory, enjoying rights - most notably rights to live and work anywhere in the EU, and social and political rights deriving from that free movement - by virtue of their European citizenship. ${ }^{2}$ Union citizenship is a derivative status that depends on its holder possessing the citizenship of one of the member states but it also confers its own independent entitlements and responsibilities on citizens (Maas forthcoming).

Yet the ideal of the Union as a shared space of free movement and citizenship is tempered by the existence and growth of settled populations excluded from those freedoms. By 2008, the number of third country nationals legally resident in the Union exceeded 19 million, more than double the number ( 9 million) of Union citizens resident in a state other than that of their national citizenship. Third country nationals accounted for approximately $4 \%$ of the EU population, with the largest groups originating from Turkey, Morocco, Albania and Algeria. The figures are deceptively low because many foreign-born immigrants are naturalized and cease to be counted as third country nationals (European Commission 2007). If the undetermined number of third country nationals residing in the Union without legal status are added, it becomes clear that proposals for common European policies regarding third country nationals affect a group of people larger than the populations of most of the member states.

The judges of the European Court of Justice famously wrote that 'Union citizenship is destined to be the fundamental status of nationals of the Member States, enabling those who find themselves in the same situation to enjoy the same treatment in law irrespective of their nationality' (European Court of Justice 2001). Third country nationals are left out of this formulation because they are, by definition, not nationals of a member state. Even more than the perceived second-class citizenship of transitional periods for some nationals of some new member states, the continuing exclusion of long-term resident third country nationals highlights the unfulfilled promise of Union citizenship.

This article first examines Union citizenship as a form of nested or multilevel citizenship, then considers the distinction between Union citizens and non-citizens, focusing on policy developments as evidence of Union citizenship's continuing exclusivity. Next, the attention shifts to Union citizenship's transformative potential and the persistent importance of naturalization 
into national states as the means of accessing European rights before concluding that portrayals of European citizenship as a harbinger of a post-national world order are either misguided or at best premature. In Europe, the inherent tension and balance between the universalizing function of citizenship and the defense or protection of local norms remains resolutely weighted towards the side of distinctive member state norms rather than the common standards promised by Union citizenship.

\section{Nested citizenship}

Contemporary citizenship is a creation of states, and a longstanding principle of international law specifies that each state may determine under its own laws who its citizens are (1930 Hague Convention). The development of a citizenship of the European Union therefore raises the question of its legal status and of whether or not it can fully be called citizenship in the international legal sense of the concept. In other words, the issue is whether the Union can determine under its own laws who are its citizens. The answer to this question has, to date, not been positive: the only way to become a Union citizen is by becoming a citizen of a member state. Thus it appears at first glance that EU citizenship cannot properly speaking be considered citizenship at all.

Yet the issue of the status of EU citizenship is not quite so clear-cut when compared with the various forms of nested or multilevel citizenship common in federal states, where individuals simultaneously hold citizenship in the national polity and in regional or sub-national jurisdictions (Jackson 2001, Faist 2001, Bauböck 2007). One cannot be a German citizen living in Munich, for example, without also being a Bavarian 'citizen', just as one cannot be a Canadian citizen living in Toronto without having all the rights and duties - such as access to the provincial health plan and social welfare benefits and the concomitant duty to pay provincial income and other taxes - of Ontario 'citizenship'. Of course the term 'citizen' is not always used: for example, proposals to establish a formal Québec citizenship separate from that of the federal Canadian citizenship are controversial (Oakes and Warren 2007, Bouchard and Taylor 2008). But sub-state citizenship clearly matters in many polities. In Switzerland, for example, it was only in 1983 that the constitution was changed to grant the federal authorities more authority over naturalization and the attribution of citizenship, which had previously been almost exclusively decided by the Cantons: Swiss national citizenship 'was acquired and lost as a consequence of the acquisition or loss' of cantonal citizenship, which in turn largely depended on municipal citizenship, and the Cantons continue to play a significant role in determining eligibility for Swiss citizenship: no one may be a Swiss citizen without also being a citizen of a Canton and a municipality (de Groot 1998 cited in Jackson 2001, p. 135).

Such comparative examples of nested or multilevel citizenship raise the question of what EU citizenship can become. Like the Swiss model, no one today may become an EU citizen without also becoming a citizen of a member state. But Switzerland is noteworthy for the way its system has developed and changed, particularly for the increasing role of the federal government. Decisions about Swiss citizenship were in the past almost exclusively made at the Cantonal level, but the federal government took over ever more coordination functions and authority and now sets policies that apply throughout all the Cantons. ${ }^{3}$ Similarly, in Germany, important aspects of immigration and citizenship laws have historically been administered by the länder rather than by the federal government, but the federal government sets national policy. In Germany, just as in Switzerland, the effective responsibility for citizenship matters has increasingly moved away from regional authorities towards the central government. ${ }^{4}$ In light of these examples, we can ask about the extent to which it is conceivable that the EU could take 
over coordination and policymaking functions from member states on citizenship matters, including questions of attribution and loss of citizenship.

The Swiss and German models, whereby the central government asserts ever more authority over the ability of regional governments to determine citizenship policy, may indeed be applicable to the European Union. At least as early as 1974, the European Commission was already proposing the 'stage-by-stage harmonization of legislation affecting aliens' in the context of freer movement within the Community (Bulletin EC 12-1974, point 1104 item 12). Such proposals grew alongside proposals for increased free movement. Thus the 1985 White Paper on Completing the Internal Market recognized that the abolition of checks at internal frontiers would enable not only citizens of the member states but also third country nationals to move from one member state to another. In the White Paper, the Commission therefore committed to proposing, by 1988, 'coordination of the rules on residence, entry, and access to employment for third country nationals'. It also noted that issues might 'arise over the question of the change of residence of non-Community citizens between the Member States,' and noted that 'these would need to be looked at'. Finally, the White Paper promised that 'Measures [would] be proposed also in 1988 at the latest on the right of asylum and the position of refugees'. It continued that 'decisions will be needed on these matters by 1990 at the latest' (European Commission 1985, pp. 15, 16). The timetable for coordination of rules concerning conditions of residence, entry, employment, free movement between the member states, asylum status and the position of refugees were certainly not resolved by 1990 - indeed, questions about coordination on these matters remain salient nearly two decades after that deadline. The member states have made some progress on rule-making, but the degree of coordination on each of these issues reflects the ongoing pressures of decision making within a complex, multilevel political system.

In attempting to understand the degree of coordination, it may be useful to compare the European Union with federal states. The incentive to preserve the distinctiveness of a unit in a federation by erecting barriers to movement may be particularly strong if the political community in question occupies a real or perceived minority position within the overall political structure of the federation. Each unit has an incentive to attract immigrants so as not to lose demographic weight relative to the other units. But each unit also faces pressures to protect the distinctiveness of its own political community. More broadly, central governments can adopt a range of policies to prevent constituent units from passing laws which operate against universal mobility within the common political space or which otherwise infringe on the ideal of a common homogenous citizenship. To some extent, however, the central government lacks control, as both its capacity and its authority are shared with the constituent units. This lack of control precisely matches those areas over which the component units exercise jurisdiction. In other words, the key questions involve the constitutional restrictions on the respective powers of the centre and the component units. Which level of government has authority and control over demographic factors? Which is responsible for access to employment or to social programmes such as education, health care, welfare or social security? Which has the capacity to enforce border controls or residency restrictions? As shown by the Swiss and German examples although the same holds true for other federal states as well - decisions concerning the acquisition and loss of citizenship have generally moved from the constituent units to the central government. Within the European Union, however, these decisions remain the domain of the member states.

The tension between centralized and decentralized sources of rights is a persistent theme of political life. The European Union citizenship introduced at Maastricht recalls the earlier introduction of a national layer of citizenship over existing municipal or regional versions. Until the nineteenth century, European municipalities, not states, provided residents with the rights 
that characterize citizenship: the right to reside and work, to political participation, to trial in local courts, and even to social welfare benefits (Prak 1999). The introduction in the nineteenth century of an initially 'thin' layer of nation-state citizenship rights over the existing structure of well-established, 'thick' municipal citizenships provides many parallels to the current overlaying of a 'thin' European Union citizenship over those same nation-state citizenships. As discussed above, it also parallels the development of citizenship in federal states.

In a political system in which the rights and obligations of citizenship are defined or implemented at the unit rather than the central level, social rights will take on different meanings in different contexts. Social rights can differ from one individual to another not only territorially - where the sub-state jurisdiction in which one resides determines access to social programmes - but also based on other criteria, such as veteran status or membership in a protected linguistic or cultural minority group. In the United States, federalism often serves to perpetuate illiberal and undemocratic racial, ethnic and gender hierarchies (Smith 1997). Some arguments in favour of states' rights emphasize the principle of division of powers in a federal system, arguing from the philosophy that the central government in a federation should not interfere with constituent units in areas that are outside the central government's jurisdiction. Such principled arguments are not necessarily related to substantive policy questions, but other arguments in favour of states' rights explicitly refer to the goal of maintaining intolerant local hierarchies - as the example of the States' Rights Democratic Party (popularly known as Dixiecrats) shows. ${ }^{5}$ The relationship between federalism and the maintenance of local hierarchies is therefore unsettled and permanently in tension. Similarly, in Europe, the relationship between common Union citizenship and the maintenance of the local hierarchies defended by the national citizenship of the member states reflects an enduring friction.

Because citizenship defines political actors and the rules within which they operate separating full members of the polity from others, specifying the rights and duties of each category of people, and privileging certain public identities over others - citizenship is always contentious (Maas 2007, p. 115). In many national states, both in Europe and elsewhere, the struggle for citizenship has been overwhelmingly a demand for inclusion in the polity, the social dignity attached to the right to vote, and the right to earn a living (Shklar 1991, pp. 2-3). Inclusion in the polity is the process by which segments of society previously excluded from membership in political and socioeconomic institutions are incorporated into these institutions as citizens (Eckstein 1992, p. 345).

The contemporary promise of equal inclusion in the polity should not be overstated: in many countries, the relationship between citizens and governments shifted after the zenith of the welfare state in the second half of the twentieth century from a situation in which governments provide a fixed set of services, which citizens are forced to accept, to one in which citizens face a greater range of choices and in which governments provide services à la carte (Elkins 1995). The notion of greater individual choice may be appealing, but governments' shifts from fixed menu to à la carte service provision undermines the notion of citizenship as grounded in the equal treatment of those included in the polity. Historically, one of the most powerful aspects of citizenship has been precisely its promise of equality to all citizens (Marshall 1950), yet increased individual choice of government services inevitably results in differences in programme delivery and reception. This means that the equalizing function of citizenship is eroded. Perhaps differential service provision, which to some extent erodes citizenship's ability to deliver universality and equality, is better for increasingly multicultural societies characterized by the emergence or reemergence of ethnic, linguistic, regional, religious or other differences. But the introduction or reintroduction of difference - even when justified in the name of individual freedom and liberty of choice - does challenge the possibility of achieving equality. In this sense, the trajectory of citizenship's contemporary evolution in Europe may simply reflect a wider global trend towards privileging the first of the famous triplet 
of liberty, equality and community. The increasing role for market-based à la carte rather than traditional welfare state service provision can be viewed as elevating the liberté aspect of citizenship over its egalité function. Yet citizenship's third element, that of fraternité or community, remains in question (Benhabib 2004, especially Ch. 4, Delanty 2007). As discussed in the next section, despite the promise of equality, Union citizenship has long been based on the fundamental inequality between citizens of member states and third country nationals. This impinges not only citizenship's emphasis on equality but also its promise of shared community.

\section{EU Citizens and third country nationals}

Alongside economic aims, European integration has also always reflected the political project of transcending borders and building a European community of people, a new kind of polity. Yet some who might be considered European - by virtue of their residence or even birth in Europe - have always been excluded: a clear distinction between the rights of Community citizens and those of third country nationals has been present since the postwar origins of European integration (Maas 2005b). Although Union citizenship is not incompatible with institution building and polity formation beyond the nation state, it has from its earliest conceptions been grounded in national citizenship, with the 'additionality' of European status derived from national membership (Olsen 2008a, p. 55, 53), making Union citizenship transnational rather than supranational (Olsen 2008b, p. 238). This situation did not change with the formal introduction of Union citizenship: third country nationals and citizens of member states continued to be treated differently (Evans 1994). Despite or perhaps because of their exclusion from European status, immigrants from third countries have also always circumvented legal restrictions on their residence and work within member states. In other words, member states have never been able to fully control entry into either their borders or the labour market. As labour migration grew in importance and magnitude, the numbers of illegal or irregular migrants grew correspondingly. This was particularly true after European (and other) states reduced in the 1970s the legal means of immigration. Despite the restrictions, the number of third country nationals resident in the member states continued to rise.

At the same time that citizens of member states were being granted more rights by virtue of their shared membership in the European enterprise, citizens of third countries saw their rights frozen or reduced. Most importantly, the early decision to restrict free movement provisions to nationals of member states 'biased the process of the institutional construction of a European identity by filtering out alternative considerations about a civic and inclusive mode of European identity' (Kostakopoulou 2001, p. 62). By identifying and promoting special rights for citizens of member states rather than all European residents, the architects of EU citizenship ensured the replacement of one dichotomy with another: the separation between citizen and foreigner has gradually been replaced by the distinction between European and non-European. Today it matters much less whether one holds French or German or Italian citizenship than it did in the past. But at the same time it matters much more whether or not the citizenship one holds means access to EU citizenship, which to date has always been restricted to citizens of the member states.

The decreasing importance of the distinction between different member state citizenships and the corresponding increase in importance of the differentiation between holders of European and non-European citizenships - reflects the transformation in the nature of the Union from being essentially an extension of the common market to becoming a shared political space. Thus a former Spanish Foreign Minister and member of the presidium which drafted the Constitutional Treaty declared in 2003 that, 'Until now, Europe was mainly associated with a common market. Now Europe will be more and more a place of citizenship' (Maas 2007, p. 77). Yet it is unclear whether the view of Europe as a place of citizenship necessitates such sharp 
distinctions between insiders and outsiders, between Europeans and non-Europeans. Indeed, the constitutional treaty - expanding on provisions of the Amsterdam Treaty, discussed below provided that the Union would develop a common immigration policy aimed at ensuring, among other things, 'fair treatment of third country nationals residing legally in Member States' (Treaty Establishing a Constitution for Europe, Art. III-267). Common European standards for the fair treatment of third country nationals would mean a stronger European role in guaranteeing common rights for third country national residents.

The European role in coordinating or supervising the rights of third country nationals is complex and made more so by the fact that not all third country nationals are treated alike. The existence of bilateral accords between third countries and the Union (or between third countries and member states signed before those member states entered the Union but still in effect) means that nationals of some third countries are accorded rights that other third country nationals do not have. This is particularly true for citizens of Turkey, who are the largest group of third country nationals residing in the EU, and to a lesser extent for citizens of Morocco and Algeria. If third country nationals constituted a single group and had rights equivalent in all the member states then Union citizenship would have more meaning. But third country nationals continue to have different rights in the different member states.

The parallel development of European citizenship and concern for the rights of third country nationals can be traced back at least as early as the 1974 Paris European Council, at which the government leaders resolved both to try to identify granting member state citizens 'special rights as members of the Community' and to consider 'establishing a passport union', meaning a 'stage-by-stage harmonization of legislation affecting aliens' (European Council 1974). Of course free movement and the abolition of border controls necessitate coordination (Maas 2005a). The Maastricht Treaty introduced the formal category of Union citizenship and, as discussed in the next section, raised hopes that third country nationals could be granted Union citizenship and thus be included European polity. Yet the Amsterdam Treaty limited the scope of Union citizenship, specifying that it would remain derivative of national citizenship. Importantly, the Amsterdam Treaty consolidated and extended the European role in attempting to develop common immigration provisions, but these have proven difficult to coordinate. The broad trend is for gradual efforts to improve the coordination of the rights of third country nationals but with the major difference remaining between the rights accorded to third country nationals and those available only to Union citizens.

When Europe's leaders decided at the Cologne European Council in June 1999 to establish a Charter of Fundamental Rights that would consolidate the rights guaranteed by the European Convention on Human Rights, the European Social Charter, the Community Charter of the Fundamental Social Rights of Workers, and member state constitutional traditions, they specified that the proposed Charter should also identify the 'rights that pertain only to the Union's citizens' (European Council 1999a, annex IV). Identifying the rights that pertain only to Union citizens - rather than all Union residents or everyone covered by Union law - was viewed as a way of increasing the EU's legitimacy by strengthening Union citizenship (Schönlau 2005, p. 86). Similarly, the European Parliament in September 1999 resolved that 'the creation of an ever closer union among the peoples of Europe' was 'inseparably linked with the task of increasing, in addition to fundamental rights, citizens' rights, namely the political, economic and social rights associated with Union citizenship' (European Parliament 1999, preamble T), thus repeating the distinction between human rights and rights specifically for Union citizens. The final text of the Charter of Fundamental Rights expands the social rights extended to Union citizens but distinguishes between the rights of Union citizens and others in a confusing mix of categories. For example, the Charter's article on the freedom to choose an occupation and the right to work contains three separate categories of rights holders: everyone has the right to engage 
in work and to pursue a freely chosen or accepted occupation; only EU citizens have the freedom to seek employment, to work, to exercise the right of establishment, and to provide services in any member state; and third country nationals authorized to work in the member states are entitled to working conditions equivalent to those of EU citizens.

At the Tampere European Council in October 1999, European government leaders famously called for a common approach to the integration of third country nationals, emphasizing that the 'European Union must ensure fair treatment of third country nationals who reside legally on the territory of its Member States' by means of a 'more vigorous integration policy' aimed at 'granting them rights and obligations comparable to those of EU citizens' (European Council 1999b). Alongside tougher measures against discrimination, racism and xenophobia, the Council called for harmonization of national legislation on the conditions for admission and residence of third country nationals, and agreed that the legal status of third country nationals should be approximated to that of member state citizens and that holders of long-term residence permits should be granted 'a set of uniform rights which are as near as possible to those enjoyed by EU citizens', such as rights to reside, receive education and work as an employee or self-employed person, as well as the principle of non-discrimination (ibid.). Finally, the Council endorsed the 'objective that long-term legally resident third country nationals be offered the opportunity to obtain the nationality of the Member State in which they are resident' (ibid.). Tampere thus highlighted the issues, but did not explicitly suggest extending Union citizenship.

Before and during the constitutional Convention, the European Commission promoted the notion of civic citizenship for facilitating integration, arguing that immigrants 'should be helped to settle successfully into society through the acquisition of certain core rights, with the corresponding obligations' (European Commission 2003, p. 30). These core rights - including the right to vote and run for office at local level - would prepare immigrants to acquire full citizenship. Furthermore, the Commission promoted naturalization as an integration strategy: it welcomed the easier conditions for naturalization in some member states and promised to exchange information about best practices concerning the implementation of national citizenship laws.

The Commission's proposals did not go quite as far as other proposals to decouple national from Union citizenship, so that Union citizenship could be granted based on residence rather than nationality. A resolution by the Economic and Social Committee (ESC), for example, advocated granting Union citizenship to long-term resident third country nationals as a means of fostering their integration (European Economic and Social Committee 2002). Many immigrants could be expected to settle permanently in Europe, while mobility between member states would increase further as freedom of movement evolved. Under these conditions, the ESC argued, equality between all residents - EU citizens and third country nationals - is 'a sine qua non for integration. A community cannot have living within its midst some people who are debarred from the political and other rights enjoyed by those "foreigners" who are Member State nationals' (European Economic and Social Committee 2003). The problem, the ESC argued, was that such distinctions between Union citizenship and third country nationals were discriminatory, and 'such discrimination on the grounds of nationality must be eliminated' (ibid). Logically, extending the principle of nondiscrimination to third country nationals in this way would eliminate the possibility of any distinctions in the rights of third country nationals and those of Union citizens.

The notion that legally resident third country nationals should have the same status as citizens of the member states prompted the development of what became known as the long term residents directive (European Council 2003b). As a result of the directive, member states now grant many third country nationals long-term resident status after five years' continuous legal residence, 
following which they may have rights of residence throughout the EU, fostering their free movement within Europe. The long-term residents directive and related ones on family reunification and free movement (European Council 2003a, 2004) do grant third country nationals new rights, but they remain limited in scope and do not achieve the Tampere goal of bringing third country nationals to 'near equality' with Union citizens (Halleskov 2005). ${ }^{6}$ Meanwhile, progress on a common immigration policy remains sporadic, with most coordination concerning illegal migration. A proposal for a European 'blue card' which would allow migrants to work in any member state and consolidate the visa and work permit requirements into a single process has not yet been approved. If it is, then its implementation will reflect the continuing tensions between the centralizing efforts of Union institutions and the desire of member states to retain local norms. Third country nationals legally residing in the member states do have more rights than persons who do not have any European status. This is the added value of European law and it should not be dismissed as entirely unimportant. Yet the extent of these special European rights for those with legal residence is far from equal to the rights conferred by Union citizenship, let alone those of full citizenship in the traditional sense.

\section{Immigration, naturalization, and EU citizenship's unfulfilled potential}

The formal introduction of Union citizenship in the Maastricht Treaty led many commentators to imagine it as a new kind of citizenship that 'transcends the limits of the myth of the nation and decouples the practice of citizenship from being the member of a national community defined by birth or territorality' (Eder and Giesen 2001, p. 263). As some noted, however, if European citizenship were to become a 'genuine form of citizenship beyond the nation-state and "mature" as an institution,' then the normative foundations and boundaries of membership in the European polity would need to be rethought (Kostakopoulou 2001, p. 79). The key notion behind this transformative view of European citizenship is that it would transcend the limitations of the nationality model and instead foster the creation of a community of expectations and civic engagement, a democratic polity that takes difference seriously while remaining inclusive. In other words, among other things a truly transformative Union citizenship would acknowledge citizens' multiple identifications therefore accord rights based on domicile or residence rather than nationality, focus on social membership, conceive of rights as tools for individual empowerment; encourages participation in democratic decision making by all residents of Europe (ibid.). European citizenship is thus a 'unique experiment for stretching social and political bonds beyond national boundaries and for creating a political community in which diverse peoples become associates in a collective experience and institutional designers' (Kostakopoulou 2007, p. 624). At the simplest level, this would mean allowing third country nationals to acquire European citizenship without needing to acquire national citizenship (Becker 2004, Weiss and Wooldridge 2002, p. 168).

This idea that third country nationals should acquire Union citizenship by virtue of their residence rather than by the process of naturalization into member states received widespread support from immigrant organizations and non-governmental organizations; one petition provided that 'any individual who resides on the territory of a member State or who is a national of a member State gains citizenship of the Union' (European Association for the Protection of Human Rights and its member associations, cited in Dell'Olio 2005). Yet it is an idea that appears to be difficult for member states to accept. Holding the citizenship of a member state has always been and remains central to the acquisition of European rights (Geddes 2000, p. 58), and member states want to retain control over access to their national citizenship. This leads some to conclude that European citizenship may well become more exclusive, as third country nationals are excluded from rights which were previously available to them; this enhances a well defined and 
demarcated identity for Union citizenship but clearly does not foster the fraternité, community, or solidarity between Union citizens and third country nationals (Reestman and Besselink 2007, p. 4).

The promise of European citizenship, like the promise of national citizenship, is that of equality and of inclusion in the polity. Alongside inclusion in the polity - whether national or European - citizenship also means access to concrete benefits. Such pan-European access has been increasing for citizens of member states (Maas 2008). For many years, member states could deny social welfare rights to citizens of other member states on the basis that they were not citizens of the state in question. The prerogative of states to discriminate on the basis of nationality to determine access to social welfare benefits was gradually reduced, however, and nationality criteria can now no longer be used to protect or regulate access to social benefits for EU citizens: European law demands the de-nationalization of European welfare states, although it does not necessarily order the de-territorialization of welfare states (Van der Mei 2005, p. 207). Thus some benefits such as social assistance and student maintenance grants can be reserved for residents, to the exclusion of non-residents. This means that residence rather than nationality determines crossborder access to some tax-funded social welfare benefits ( $\mathrm{ibid}$.). Of course, if EU citizens residing outside their state of origin cannot access some welfare benefits from their state of origin, third county nationals cannot access those benefits either. And while EU citizens residing outside their state of origin can benefit from an increasing range of benefits derived from their host state, by virtue of their Union citizenship, third county nationals are in a much more precarious position.

Because of continuing opposition in the member states to granting third country nationals extensive rights as EU citizens who do not hold member state citizenship - a development that would mean the decoupling of the current link between member state and Union citizenship the best strategy for third country nationals who seek incorporation and rights may well remain the same as it always has been: to seek naturalization in their member state of residence. Indeed, some argue that the most politically feasible way to foster inclusive Union citizenship lies not in promoting Union citizenship over national citizenship but rather in encouraging member states to more easily grant dual nationality (Hansen 1998). Certainly such an approach could ease the situation of one group of third country nationals, the many thousands of people who have lived for decades in the Baltic states as Russian citizens, but do not enjoy the rights of Union citizenship because the member states in which they live - primarily Estonia and Latvia - make it difficult for them to acquire national citizenship. Perhaps it would indeed be more advisable to pressure member states to grant such persons national citizenship rather than further developing a special category of citizenship for third country nationals.

Because of the rights attached to Union citizenship, which can so far be acquired only by acquiring citizenship in a member state, policies concerning nationality law in any one member state have ramifications in the other member states. This means that there are inherent pressures for coordination. But naturalization - or nationality law more broadly - is closely related to immigration policy, and changing norms surrounding integration make it harder for immigrants to immigrate to Europe. At the same time, immigrant integration policies and outcomes continue to be shaped by national institutions rather than European norms (Ireland 2004). In purely demographic terms, if they are to maintain stable populations then European states either need to increase their birthrates or admit large numbers of immigrants. Every EU member state and applicant country - with the sole exception of Turkey, where birth rates are also dropping but still remain higher than other European states - has birth rates below replacement rate. The demographic situation is particularly grave in the newest member states of central and eastern Europe. As this article has shown, the idea that EU citizenship could provide one way of redressing the rights imbalance between different categories of European residents is far from new. But years of discussions have not provided significant and durable rights to those who are not citizens of a member state. 


\section{Conclusion: becoming European?}

The 'genuine political community' that would safeguard European values and transcend nationality has evolved significantly since the postwar era. A common status for Europeans is formalized in a common, supranational citizenship that extends important rights to member state citizens, most notably rights of residence and employment throughout EU territory. But the promise of European citizenship remains unfulfilled for third country nationals, those who are not citizens of any member state. The continuing tensions between the universalizing function of a central citizenship and decentralized sources of local rights highlights the contingent nature of all rights in compound polities. In Europe, calls continue for a citizenship based on residence and a status for third country nationals that would be common through all the member states. This would mean a decoupling of member state and Union citizenship, so that not all Union citizens would necessarily hold citizenship in a member state. If such calls ultimately succeed, then EU citizenship would truly come to signify membership in a polity that is not simply multinational but that also supersedes nationality. Immigrants could come to the Union and become European rather than French or German, British or Dutch, and so on. The importance of borders would recede even further, and residence would prevail over nationality. The question of the extent to which such calls are idealistic and impracticable remains open. For the moment, European citizenship appears to depend firmly on member state citizenship, as it has done since its origins, just as citizenship more generally continues to mean acquiring status and rights in particular nation-states, as it has done since at least the end of the nineteenth century. The idea of EU citizenship as a post-national form of political membership appears, for the moment at least, to remain more dream than reality.

\section{Notes}

1. I gratefully acknowledge the useful suggestions of Michael Lister and three anonymous reviewers, and a Glendon College faculty research grant which enabled me to consult the proceedings of the 1948 Congress of Europe at the Dutch National Archives in The Hague. An earlier version of this article was presented at conferences of the Council for European Studies, Chicago (March 2008), and European Community Studies Association Canada, Edmonton (September 2008), and I thank the discussants and audience for their helpful comments.

2. The literature on EU citizenship is vast and growing. Among the more notable major works are Meehan 1993, Closa 1995, Jessurun d'Oliveira 1995, O’Leary 1996, Wihtol de Wenden 1997, Shaw 1997. Preuss and Everson 1997, Dollat 1998, Wiener 1998, La Torre 1998, Magnette 1999, Weiler 1999, Koslowski 2000, Eder and Giesen 2001, Lehning 2001, Guild 2004, Balibar 2004, Dell'Olio 2005, Vink 2005, Shaw 2007, Maas 2007 and Olsen 2008b.

3. Even though the federal government plays a more significant role than in the past, municipalities retain much authority and some municipalities pursue more restrictive citizenship policies than others (Helbling 2008).

4. I thank Simon Green for suggesting this point. Yet in Germany, as in Switzerland, the role of the central government remains circumscribed (Fahrmeir 2008).

5. I thank Rogers Smith for pointing out the distinction between principled support and politicallymotivated support for states' rights. The States' Rights Democratic Party under the leadership of Strom Thurmond broke away from the Democratic Party in the 1948 election in the United States because of President Truman's support for abolishing racial segregation. The issue of desegregation set the stage for the Republican Party's 'Southern Strategy' of exploiting racism to capture previously Democratic southern states, which in subsequent decades became overwhelmingly Republican.

6. Although the 2004 directive formally applies only to EU citizens and their family members (who may be third country nationals), commentators expect the European Court of Justice to apply them more broadly, resulting in a convergence of the free movement rights of EU citizens and third country nationals (Slot and Bulterman 2005). 


\section{References}

Balibar, É., 2004. We, the people of Europe? Reflections on transnational citizenship. Translated by J. Swenson. Princeton, NJ: Princeton University Press.

Bauböck, R., 2007. Political boundaries in a multilevel democracy. In: S. Benhabib, I. Shapiro and D. Petranović, eds. Identities, affiliations, and allegiances. Cambridge: Cambridge University Press.

Becker, M.A., 2004. Managing diversity in the European Union: inclusive European citizenship and thirdcountry nationals. Yale human rights \& development law journal, 7, 132-152.

Bellamy, R., 2008. Evaluating Union citizenship: belonging, rights and participation within the EU Citizenship studies, 12 (6), 597-611.

Benhabib, S., 2004. The rights of others: aliens, residents and citizens. Cambridge: Cambridge University Press.

Bouchard, G. and Taylor, C., 2008. Building the future: a time for reconciliation. Report of the Consultation Commission on Accommodation Practices Related to Cultural Differences. Montreal: Government of Quebec.

Bulletin EC 12-1974, point 1104 item 12.

Closa, C., 1995. Citizenship of the Union and nationality of member states. Common market law review, 32, 487-518.

de Groot, G.-R., 1998. The relationship between the nationality legislation of the member states of the European Union and European citizenship. In: M. La Torre, ed. European citizenship: an institutional challenge. The Hague: Kluwer Law International, 115-148.

Delanty, G., 2007. European citizenship: a critical assessment. Citizenship studies, 11 (1), 63-72.

Dell'Olio, F., 2005. The Europeanization of citizenship: between the ideology of nationality, immigration, and European identity. Aldershot: Ashgate.

Dollat, P., 1998. Libre circulation des personnes et citoyenneté européenne: enjeux et perspectives. Brussels: Bruylant.

Eckstein, H., 1992. Regarding politics: essays on political theory, stability, and change. Berkeley, CA: University of California Press.

Eder, K. and Giesen, B., 2001. Citizenship and the making of a European society: from the political to the social integration of Europe. In: K. Eder and B. Giesen, eds. European citizenship between national legacies and postnational projects. Oxford: Oxford University Press, 245-269.

Elkins, D.J., 1995. Beyond sovereignty: territory and political economy in the twenty-first century. Toronto: University of Toronto Press.

European Commission, 1985. Completing the internal market. White Paper. COM(85) 310.

European Commission, 2003. Immigration, integration and employment. COM(2003) 336.

European Commission, 2007. Third annual report on migration and integration. $\operatorname{COM(2007)} 512$.

European Council, 1974. Summit conference of heads of state or government, 9 and 10 December. Bull. EC 12-74.

European Council, 1999a. Presidency conclusions, Cologne European Council, 3 and 4 June.

European Council, 1999b. Presidency conclusions, Tampere European Council, 15 and 16 October.

European Council, 2003a. Council Directive 2003/86/EC of 22 September 2003 on the right to family reunification. OJ L 251, 3 October.

European Council, 2003b. Directive 2003/109/EC of 25 November 2003 concerning the status of third-country nationals who are long-term residents. OJ L 16, 23 January 2004.

European Council, 2004. Directive 2004/38/EC of the European Parliament and of the Council of 29 April 2004 on the right of citizens of the Union and their family members to move and reside freely within the territory of the member states amending Regulation (EEC) No. 1612/68 and repealing Directives 64/221/EEC, 68/360/EEC, 72/194/EEC, 73/148/EEC, 75/34/EEC, 75/35/EEC, 90/364/EEC, 90/365/EEC and 93/96/EEC. OJ L 158, 30 April, 77.

European Court of Justice, 2001. Case C-184/99, Rudy Grzelczyk v Centre public d'aide sociale d'Ottignies-Louvain-la-Neuve (2001) ECR I-6193, 20 September.

European Economic and Social Committee, 2002. Resolution addressed to the European Convention CES $1069 / 2002$.

European Economic and Social Committee, 2003. Opinion of the European Economic and Social Committee on access to European Union citizenship CES 593/2003.

European Parliament, 1999. Resolution on the establishment of the Charter of Fundamental Rights (16 September). OJ 2000 C 54/04, 25 February, 93.

Evans, A., 1994. Third country nationals and the Treaty on European Union. European journal of international law, 5, 199-219. 
Fahrmeir, A., 2008. Citizenship: the rise and fall of a modern concept. New Haven, CT: Yale University Press.

Faist, T., 2001. Social citizenship in the European Union: nested membership. Journal of common market studies, 39 (1), 37-58.

Geddes, A., 2000. Immigration and European integration: towards Fortress Europe? Manchester: Manchester University Press.

Guild, E., 2004. The legal elements of European identity: EU citizenship and migration law. The Hague: Kluwer Law International.

Halleskov, L., 2005. The long-term residents directive: a fulfilment of the Tampere objective of nearequality? European journal of migration and law, 7 (2), 181-202.

Hansen, R., 1998. A European citizenship or a Europe of citizens? Third country nationals in the EU. Journal of ethnic and migration studies, 24 (4), 751-769.

Helbling, M., 2008. Practising citizenship and hetrogeneous nationhood: naturalisations in Swiss municipalities. Amsterdam: Amsterdam University Press.

Ireland, P.R., 2004. Becoming Europe: immigration, integration, and the welfare state. Pittsburgh, PA: University of Pittsburgh Press.

Jackson, V.C., 2001. Federalism and citizenship. In: T.A. Aleinikoff and D. Klusmeyer, eds. Citizenship today: global perspectives and practices. Washington, DC: Carnegie Endowment for International Peace, $127-182$.

Jessurun d'Oliveira, H.U., 1995. Union citizenship: pie in the sky? In: A. Rosas and E. Antola, eds. A citizen's Europe: in search of a new order. London: Sage, 58-84.

Joppke, C., 2008. Immigration and the identity of citizenship: the paradox of universalism. Citizenship studies, 12 (6), 533-546.

Koslowski, R., 2000. Migrants and citizens: demographic change in the European state system. Ithaca, NY: Cornell University Press.

Kostakopoulou, D., 2001. Citizenship, identity and immigration in the European Union: between past and future. Manchester: Manchester University Press.

Kostakopoulou, D., 2007. European Union citizenship: writing the future. European law journal, 13 (5), 623-646.

La Torre, M., 1998. European citizenship: an institutional challenge. The Hague: Kluwer Law International.

Lehning, P.B., 2001. European citizenship: towards a European identity? Law and philosophy, 20 (3), 239-282.

Maas, W., 2005a. Freedom of movement inside 'Fortress Europe'. In: E. Zureik and M.B. Salter, eds. Global surveillance and policing: borders, security, identity. Cullompton: Willan, 233-245.

Maas, W., 2005b. The genesis of European rights. Journal of common market studies, 43 (5), 1009-1025.

Maas, W., 2007. Creating European citizens. Lanham, MD: Rowman \& Littlefield.

Maas, W., 2008. Another piece of Europe in your pocket: the European health insurance card. In: C.J. Bennett and D. Lyon, eds. Playing the identity card: surveillance, security and identification in global perspective. New York: Routledge, 268-79.

Maas, W., Forthcoming. Unrespected, unequal, hollow?: contingent citizenship and reversible rights in the European Union. Columbia journal of European Law, 15(2).

Magnette, P., 1999. La citoyenneté européenne: Droits, politiques, institutions. Bruxelles: Éditions de l'Université de Bruxelles.

Marshall, T.H., 1950. Citizenship and social class and other essays. Cambridge: Cambridge University Press.

Meehan, E.M., 1993. Citizenship and the European Community. London: Sage.

O'Leary, S., 1996. The evolving concept of community citizenship: from the free movement of persons to Union citizenship. The Hague: Kluwer Law International.

Oakes, L. and Warren, J., 2007. Language, citizenship and identity in Quebec. Basingstoke: Palgrave Macmillan.

Olsen, E.D.H., 2008a. The origins of European citizenship in the first two decades of European integration. Journal of European public policy, 15 (1), 40-57.

Olsen, E.D.H., 2008b. Transnational European citizenship: tracing conceptions of citizenship in the European integration process. Dissertation (PhD). European University Institute, Italy.

Prak, M., 1999. Burghers into citizens: urban and national citizenship in the Netherlands during the Revolutionary Era (c. 1800). In: M. Hanagan and C. Tilly, eds. Extending citizenship, reconfiguring states. Lanham, MD: Rowman \& Littlefield. 
Preuss, U.K. and Everson, M., 1996. Konzeptionen von 'Bürgerschaft' in Europa. Prokla, 105 (December), $543-564$.

Reestman, J.H. and Besselink, L.F.M., 2007. Dynamics of European and national citizenship: inclusive or exclusive? European constitutional law review, 3, 1-4.

Schönlau, J., 2005. Drafting the EU Charter: rights, legitimacy, and process. New York: Palgrave Macmillan.

Shaw, J., 1997. The many pasts and futures of citizenship in the European Union. European law review, 22 (6), 554-572.

Shaw, J., 2007. The transformation of citizenship in the European Union: electoral rights and the restructuring of political space. Cambridge: Cambridge University Press.

Shklar, J.N., 1991. American citizenship: the quest for inclusion. Cambridge, MA: Harvard University Press.

Slot, P.J. and Bulterman, M., 2005. Harmonization of legislation on migrating EU citizens and third country nationals: towards a uniform evaluation framework? Fordham international law journal, 29, 747-789.

Smith, R.M., 1997. Civic ideals: conflicting visions of citizenship in US history. New Haven, CT: Yale University Press.

Van der Mei, A.P., 2005. Union citizenship and the 'de-nationalisation' of the territorial welfare state: comments on Case C-456/02 Trojani and Case C-209/03 Bidar. European journal of migration and law, 7, 203-211.

Vink, M.P., 2005. Limits of European citizenship: European integration and domestic immigration policies. Basingstoke: Palgrave Macmillan.

Weiler, J.H.H., 1999. The Constitution of Europe. Cambridge: Cambridge University Press.

Weiss, F. and Wooldridge, F., 2002. Free movement of persons within the European Community. The Hague: Kluwer Law International.

Wiener, A., 1998. 'European' citizenship practice: building institutions of a non-state. Boulder, CO: Westview Press.

Wihtol de Wenden, C., 1997. La citoyenneté européenne. Paris: Presses de la Fondation nationale des sciences politiques. 